\title{
Potential for the use of coconut shell (Cocus nucifera) as an alternative fuel in the production of cassava flour
}

Potencial para uso da casca de coco (Cocus nucifera) como combustível alternativo na produção de farinha de mandioca

Potencial del uso de cáscara de coco (Cocus nucifera) como combustible alternativo en la producción de harina de yuca

\author{
Carolina Oliveira Souza \\ ORCID: https://orcid.org/0000-0001-9876-4305 \\ Universidade Federal de Sergipe, Brazil \\ E-mail: carolina.o.souza20@gmail.com \\ André Luis Dantas Ramos \\ ORCID: https://orcid.org/0000-0003-3610-6037 \\ Universidade Federal de Sergipe, Brazil \\ E-mail: aldramos@gmail.com \\ Ananias Francisco Dias Júnior \\ ORCID: https://orcid.org/0000-0001-9974-0567 \\ Universidade Federal do Espírito Santo, Brazil \\ E-mail: ananiasjr@usp.br \\ Milton Marques Fernandes \\ ORCID: https://orcid.org/0000-0002-9394-0020 \\ Universidade Federal de Sergipe, Brazil \\ E-mail: miltonmf@gmail.com \\ José Jailton Marques \\ ORCID: https://orcid.org/0000-0001-6927-6089 \\ Universidade Federal de Sergipe, Brazil \\ E-mail: tonilja@outlook.com
}

\begin{abstract}
The production of cassava and tapioca flour are recognized as activities merged in family culture in the North and Northeast regions of Brazil, which demand the use of firewood to feed the furnaces in the flour mills. Due to the small number of studies on this theme, this work aims to evaluate the quality of woody species commonly used as solid fuels in the production of manioc flour in the state of Sergipe, namely: Poincianella pyramidalis ("catingueira"), Cronton sonderianus ("marmeleiro") and Piptadenia stipulacea (white "jurema"), as well as coconut shells (Cocos nucifera), as an alternative to the use of woody species. Representative samples of the materials were analyzed for parameters: total extracts, lignin, holocellulose, volatile materials, fixed carbon, ashes, higher (HHV) and lower (LHV) heating values, in addition to thermogravimetric analysis. The data were analyzed in a completely randomized design, with four treatments and three replications. The species Piptadenia stipulacea and Cocos nucifera showed high contents of total extracts $(18.14 \% ; 29.81 \%)$, lignin $(29.14 \% ; 28.18 \%)$ and fixed carbon $(28.22 \% ; 29.62 \%)$, and lower contents of holocellulose $(52.72 \% ; 42.01 \%)$ and volatile materials $(70.60 \% ; 66.14 \%)$, respectively. The species with the lowest ash content were Croton sonderianus and Piptadenia stipulacea, and the species with the highest HHV and LHV were Piptadenia stipulacea and Croton sonderianus, respectively. Regarding to the thermogravimetric properties, Cocos nucifera behaved like the other biomasses, with ignition temperature slightly lower and peak temperature higher than those for the other species. Among the species analyzed, Piptadenia stipulacea and Cocos nucifera showed the best results as combustibles for cassava flour production. Hence, dried Cocos nucifera shells can properly replace the conventional firewood.
\end{abstract}

Keywords: Biomass; Flour mills; Cassava; Cocos nucifer; Piptadenia stipulacea; Combustion.

\section{Resumo}

A produção de farinha de mandioca e de tapioca se destacam como atividades enraizadas na cultura familiar nas regiões Norte e Nordeste do Brasil, as quais demandam o uso de lenha para alimentar os fornos das casas de farinha. Devido ao pequeno número de trabalhos nesta temática, objetivou-se avaliar a qualidade de espécies lenhosas comumente utilizadas como combustíveis sólidos na produção de farinha de mandioca no estado de Sergipe, a saber: Poincianella pyramidalis (catingueira), Cronton sonderianus (marmeleiro) e a Piptadenia stipulacea (jurema branca), bem como cascas do Cocos nucifera (coco verde), como alternativa ao uso das espécies lenhosas. Amostras representativas dos 
materiais foram analisadas quanto aos parâmetros: extrativos totais, lignina, holocelulose, materiais voláteis, carbono fixo, cinzas, poderes caloríficos superior $(P C S)$ e inferior (PCI), além de análise termogravimétrica. Os dados foram analisados em delineamento inteiramente casualizado, com quatro tratamentos e três repetições. As espécies Piptadenia stipulacea e Cocos nucifera apresentaram teores elevados de extrativos totais $(18,14 \% ; 29,81 \%)$, lignina $(29,14 \%$; $28,18 \%)$ e carbono fixo $(28,22 \% ; 29,62 \%)$, e menores teores de holocelulose $(52,72 \% ; 42,01 \%)$ e materiais voláteis $(70,60 \% ; 66,14 \%)$, respectivamente. Já as espécies com menores teores de cinzas foram o Croton sonderianus e a Piptadenia stipulacea. As espécies que apresentaram maiores PCS e PCI foram a Piptadenia stipulacea e o Croton sonderianus. Com relação à análise termogravimétrica, os dados revelam que o Cocos nucifera apresentou comportamento similar ao das demais biomassas, com temperatura de ignição levemente inferior e temperatura de pico superior às das demais espécies. Dentre as espécies analisadas, a lenhosa Piptadenia stipulacea e o Cocos nucifera foram as que apresentaram melhores resultados para a produção de farinha, conferindo à casca do Cocos nucifera o status de possível substituto da lenha como combustível.

Palavras-chave: Biomassa; Casas de farinha; Mandioca; Cocos nucifera; Piptadenia stipulacea; Combustão.

\section{Resumen}

La producción de harina de yuca y tapioca se destaca como actividades arraigadas en la cultura familiar en las regiones Norte y Nordeste de Brasil, que demandan el uso de leña para alimentar los hornos en las casas harineras. Debido al escaso número de estudios sobre este tema, el objetivo de este trabajo fue evaluar la calidad de especies leñosas comúnmente utilizadas como combustibles sólidos en la producción de harina de mandioca en el estado de Sergipe, a saber: Poincianella pyramidalis ("catingueira"), Cronton sonderianus ("marmeleiro") y Piptadenia stipulacea ("jurema" blanca), así como corteza de Cocos nucifera (coco verde), como alternativa al uso de especies leñosas. Se analizaron muestras representativas de los materiales para parámetros: extractos totales, lignina, holocelulosa, materiales volátiles, carbono fijo, cenizas, poder calorífico superior (PCS) e inferior (PCI), así como del análisis termogravimétrico. Los datos se analizaron en un diseño completamente al azar, con cuatro tratamientos y tres repeticiones. Las especies Piptadenia stipulacea y Cocos nucifera mostraron altos niveles de extractos totales (18,14\%; $29,81 \%)$, lignina $(29,14 \% ; 28,18 \%)$ y carbono fijo $(28,22 \% ; 29,62 \%)$, y menores niveles de holocelulosa $(52,72 \%$; $42,01 \%) . \%)$ y materiales volátiles $(70,60 \% ; 66,14 \%)$, respectivamente. Las especies con menor contenido de cenizas fueron Croton sonderianus y Piptadenia stipulacea. Las especies con mayor PCS e PCI fueron Piptadenia stipulacea y Croton sonderianus. En cuanto al análisis termogravimétrico, los datos revelan que Cocos nucifera presentó un comportamiento similar al de las otras biomasas, con temperatura de ignición levemente menor y temperatura pico superior a la de las otras especies. Entre las especies analizadas, la leñosa Piptadenia stipulacea y Cocos nucifera mostraron los mejores resultados para la producción de harina, otorgando a la corteza de Cocos nucifera la condición de posible sustituto de la leña como combustible.

Palabras clave: Biomasa; Harineros; Mandioca; Cocos nucifera; Piptadenia stipulacea; Combustión.

\section{Introduction}

Vegetable biomass can be used both as a fuel for direct heating, and can be converted into solid, liquid or gaseous derivatives, for the generation of heat, electricity or fuels for use in various sectors of the economy. According to Vassilev et al. (2013), about $97 \%$ of the world's bioenergy is produced by direct combustion of biomass - one of the techniques widely used for commercial and industrial use. However, one of the challenges for the development of this energy source is the conflict in land use between food production and biomass production (Wicke et al., 2011; Muscat et al., 2020).

According to Jan (2012), a prominent issue is the dependence of part of the low-income world population on biomass, to meet their energy needs. The intensive and uncontrolled use of biomass creates environmental threats, which is restricted by the availability of arable land and natural resources such as water (Guo et al., 2020a). In addition, the burning of vegetable biomass results in different health impacts, due to the high levels of exposure to air pollution in the domestic environment, due to the use of inefficient cooking stoves and bad ventilation conditions, besides the forest degradation due to removal of firewood, contributing to the global warming (Ahrends et al., 2010; Hosonuma et al., 2012; Quinn et al., 2018).

Most people living in rural areas in developing Asian and sub-Saharan countries face a dilemma: they have great potential for the production of agricultural biomass, but they face a lack of food and energy because they depend directly on burning biomass as a source of energy and heating (Campbell et al., 2008; Foel et al., 2011; Wicke et al., 2011; Lewis \& Pattanayak, 2012; Brady et al., 2017). Ninety percent of bioenergy is consumed inefficiently as firewood, coal and agricultural 
waste, and the responsibility for obtaining the energy source is exclusive to women, explaining the dilemma (Guo et al., 2020a; Wicke et al., 2011; Ruiz-Mercado et al., 2011).

According to Gnansounou et al. (2020), West Africa presents climatic zones with semi-arid areas vulnerable to drought and climate change, which threaten agricultural activities, water resources and ecosystem services such as biomass for energy production. The neotropical region of the Brazilian Semi-Arid has the biome known as the caatinga, encompassing much of the Northeast region of Brazil, characterized by low rainfall and high evapotranspiration (Moro et al., 2016). In this part of the semiarid region, population growth and the demand for energy products have increased, intensifying pressure on native flora, aiming at obtaining firewood and charcoal, which, for a long time, were used for cooking and heating in furnaces, ovens and boilers (Gioda, 2019).

Although resources such as firewood, coal and agricultural waste are harvested unsustainably and energy conversion technologies, such as stoves and furnaces are low efficiency (Foel et al., 2011), some strategies to supply energy demand have been studied, as reported by Mehmood et al. (2019), which recommends that residual biomass from agriculture or agroforestry can be produced on non-arable land - a practical option that does not cause competition with food production. As woody species are widely used for energy purposes, different sources of biomass have also been studied as strategies for the same purpose, such as sugar cane, rice husks, sawdust, nutshells, grasses and solid residues (Rípoli et al., 2000; Mehmood et al., 2019). Another example is the use of residual biomass from Cocos nucifera (in fact, coconut shell), as studied by Yerima and Grema (2018), in Nigeria, instead of firewood, reporting its high energy content, which can be used as domestic or industrial fuel, with the purpose of reducing the removal of wood from natural ecosystems, which has been responsible for desertification in arid areas of Nigeria.

In the Northeast region of Brazil, woody species from the caatinga have been used as firewood for the production of charcoal, to meet the demand of bakeries, ceramics and small rural producers, with no management plan (Machado et al., 2010), generating environmental impact negative (APL-SE, 2011) due to the deforestation of this biome. According to Neves et al. (2017), flour is one of the main products derived from cassava, in widespread use throughout the country, especially in the North and Northeast regions of Brazil, whose production process necessarily involves a stage of roasting in wood ovens (Cereda \& Vilpoux, 2010), with controlled heating based on the firewood burning rate (Oladejo et al., 2016).

Therefore, the objective of this work was to compare the residue of Cocos nucifera and woody species from the caatinga, in order to evaluate the potential of the former as a substitute for conventional woody species in the ovens for the production of cassava (Manihot esculenta Crantz) flour.

\section{Materials and Methods}

This work emerged from an applied (since it aimed to generate new knowledge to solve specific problems) (Gil, 2010), quantitative (once properties and parameters of the samples were determined) (Marconi \& Lakatos, 2010) and experimental research (since it included laboratory studies) (Pereira et al., 2018), based on the characterization of lignocellulosic materials (wood samples) with potential for use as fuel, with regard to their properties and parameters that influence the heat capacity and performance of materials as sources of thermal energy.

The wood samples of the species Poincianella pyramidalis ("catingueira"), Cronton sonderianus ("marmeleiro") and Piptadenia stipulacea ("jurema branca") came from the municipality of São Domingos, state of Sergipe (Figure 1), a municipality with a total area of 10,247 ha, of which only $16 \%$ are covered by caatinga (IFN, 2018), being limited to the north with the municipality of Macambira, to the east with Campo do Brito, to the west and to the south with Lagarto. It has an altitude of 206 meters and geographical coordinates $10^{\circ} 47^{\prime} 31^{\prime \prime}$ south latitude and $37^{\circ} 34^{\prime} 09^{\prime \prime}$ west longitude (CPRM, 2002). The region is recognized for the high production of manioc flour (Manihot esculenta Crantz), consumed throughout the state of Sergipe and distributed to other Brazilian states. 
Figure 1. Location of the studied area.

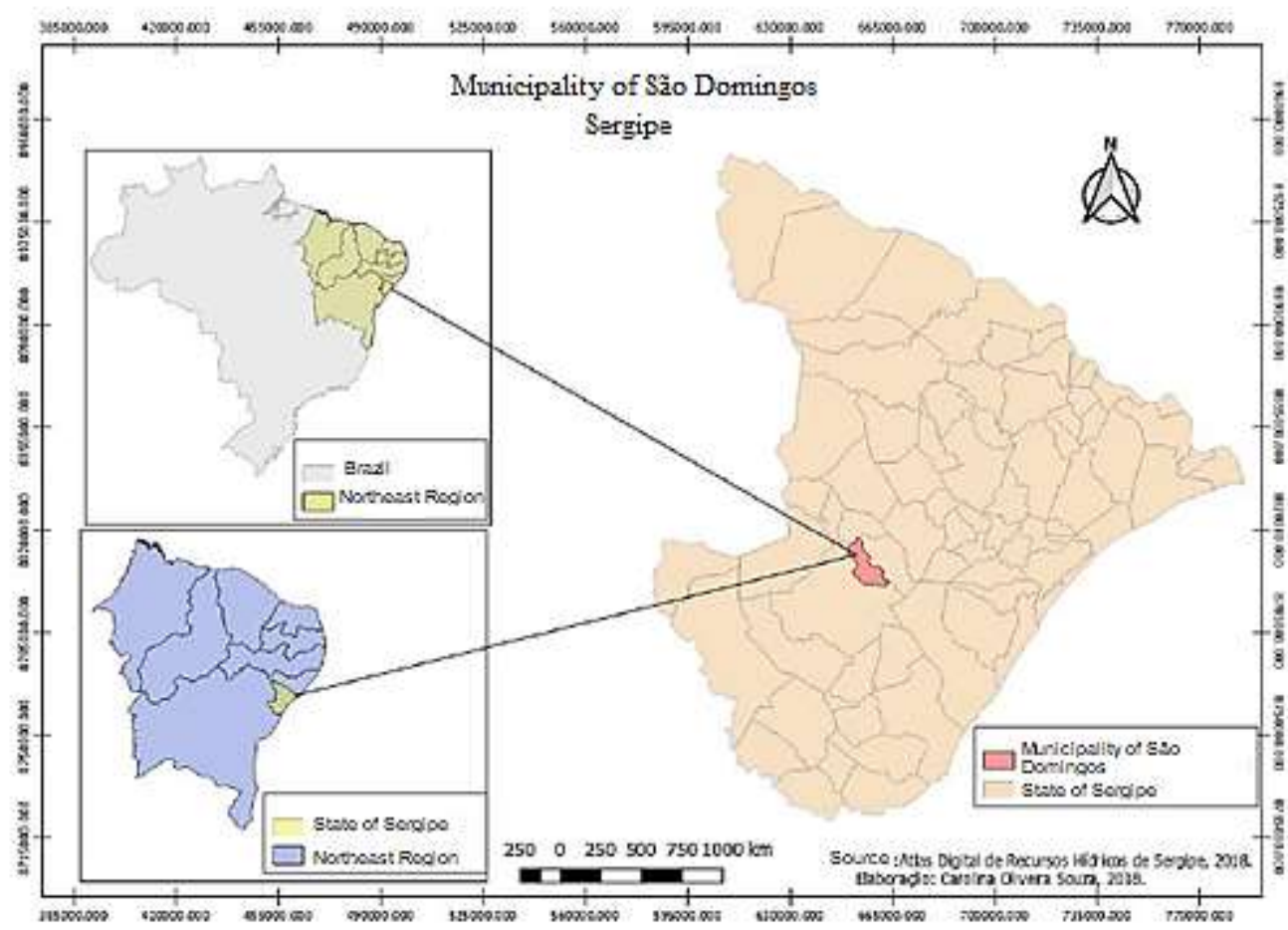

Source: Authors.

Samples of each of the investigated wood species were randomly collected, which were cut into $15 \mathrm{~cm}$ thick discs, reduced to chips (Almeida et al., 2015) and stored in zip lock bags. One exsiccates of each species was collected and later identified by comparison at the Herbarium of the Federal University of Sergipe (ASE). The samples of green coconut shells (Cocos nucifera) were obtained at a commercial coconut water selling point in Aracaju, Sergipe, Brazil, with geographical coordinates $10^{\circ} 55^{\prime} 56^{\prime}$ 'S and $37^{\circ} 04^{\prime} 23^{\prime \prime} \mathrm{W}$. Such samples were cut into small pieces and stored in a similar way to wooden ones. All samples were properly identified and transported to the laboratories for chemical, proximate and energetic analysis, described below.

The samples were transformed into sawdust in a Wiley mill, according to TAPPI T-257 om-92 (1992), and the analyzes were carried out from the sawdust fraction, classified in sieves between 40 and 60 mesh, conditioned to the temperature of $20^{\circ} \mathrm{C}$ and then stored in glass bottles, according to TAPPI T-264 cm-97 (1997). The chemical analysis followed the standardized recommendations of TAPPI T-204 cm-97 (1997) and Klock et al. (2012) adapted. Quantitative determinations of total extracts were made through a sequence of extractions with an ethanol:toluene mixture $(1: 2, \mathrm{v} / \mathrm{v})$, followed by a final extraction using only ethanol $92.8 \%(\mathrm{w} / \mathrm{w})$. Then, the quantities of lignin insoluble in sulfuric acid $72 \%$ were determined according to TAPPI T222 om-98 (1998), and the soluble lignin was determined by the spectrophotometric method in the UV range, using an absorbance scan from $280 \mathrm{~nm}$ to $215 \mathrm{~nm}$ - Goldschimid method (Morais et al., 2010). The total lignin content was obtained by adding the insoluble lignin content to the soluble lignin content. The number of holocellulose was estimated by difference (Almeida et al., 2015). To determine the contents of volatile materials and ash, standard D - 1762-64 (ASTM, 2007) was followed. The fixed carbon content was determined by difference, following the same standard. The higher heating value (HHV) of the samples was determined according to NBR 8633 (ABNT, 1984), using an Iiab C200 adiabatic calorimetric pump, in isothermal or static mode. The lower heating value (LHV) was predicted by the correlation: LHV $=$ [HHV $-(600 \times 9 \mathrm{H}) / 100]$, where LHV is the lower heating value (kcal.kg-1); HHV is the higher heating value (kcal.kg-1); and $\mathrm{H}$ is the percentage of hydrogen. 
The thermogravimetric analysis was performed on a Shimadzu TGA - 60H model equipment in which the samples were subjected to a programmed and controlled temperature variation, under nitrogen flow $\left(\mathrm{N}_{2}\right)$ and heating rate of $10^{\circ} \mathrm{C} . \mathrm{min}^{-1}$, since the room temperature $\left(25^{\circ} \mathrm{C}\right)$ up to $850^{\circ} \mathrm{C}$, following a common practice in Brazil, in systems for converting plant biomass, where temperatures are between $400^{\circ} \mathrm{C}$ and $600^{\circ} \mathrm{C}$ (Dias Júnior et al., 2019), and it is possible to obtain a continuous record of the mass variation with increasing temperature, over time, presented in graphical form.

\section{Data analysis}

To analyze the experiments, a completely randomized design was used, with four treatments (woody species and the residue of Cocos nucifera) and analyzes in triplicate. To compare the means, the F test $(\mathrm{p} \leq 0.05)$ was applied together with the Tukey test $(\mathrm{p} \leq 0.05)$ to compare the means for possible significant differences. The association between the main characteristics of woody species and the residue of Cocos nucifera was also determined by the Pearson correlation method.

\section{Results and Discussion}

\subsection{Chemical composition}

The characterization of the species studied by the direct combustion process reproduces with close proximity what occurs in ovens and furnaces for cooking food. This test identifies the values referring to the levels of total extractives, total lignin and holocellulose (Table 1).

Table 1. Content of total extractives (EXT), total lignin (LIG) and holocellulose (HOL)

\begin{tabular}{cccc}
\hline Species & EXT $(\%)$ & LIG $(\%)$ & HOL $(\%)$ \\
\hline Cocos nucifera & $29.81^{(0.63)} \mathrm{a}$ & $28.18^{(1.12)} \mathrm{b}$ & $42.01^{(0.51)} \mathrm{d}$ \\
Poincianella pyramidalis & $7.76^{(0.08)} \mathrm{c}$ & $23.13^{(0.30)} \mathrm{c}$ & $69.11^{(0.24)} \mathrm{a}$ \\
Croton sonderianus & $7.84^{(0.05)} \mathrm{c}$ & $30.27^{(0.18)} \mathrm{a}$ & $61.89^{(0.13)} \mathrm{b}$ \\
Piptadenia stipulacea & $18.14^{(0.16)} \mathrm{b}$ & $29.14^{(0.23)} \mathrm{ab}$ & $52.72^{(0.39)} \mathrm{c}$ \\
\hline
\end{tabular}

Values in parentheses refer to the standard deviation. Means followed by the same letters in the column do not differ at $5 \%$ significance, according to the Tukey test. Source: Authors.

Extractives are important components of biomass for the generation of bioenergy, since they are flammable compounds with lower molar masses than cellulose, which promote the decomposition of biomass at lower temperatures (Poletto et al., 2012). According to Protásio et al. (2019), high levels of extractives can facilitate combustion at lower temperatures, as a result of their greater volatility, accelerating the process of thermal degradation (Guo et al., 2010; Poletto, et al., 2012), which implies a biomass that is easier to burn - a relevant feature for use in roasting ovens.

The values observed for the levels of total extractives showed variations with significant differences between treatments, but lower than those found by Dias Júnior et al. (2019), for species such as Poincianella pyramidalis (15.15\%) and Piptadenia stipulacea (13.60\%). In addition, for Cocos nucifera (coconut shell), the content of total extracts was close to that observed by Cardoso and Gonçalez (2016), of 33.68\%, which indicates that this biomass easily starts burning inside the combustors, as reported by Guo et al. (2010) and Telmo and Lousada (2011).

Poincianella pyramidalis and Croton sonderianus exhibited the lowest and highest levels of lignin, respectively, with significant differences in relation to the other species studied. Protásio et al. (2013c) observed values of lignin varying between $28.01 \%$ and $35.12 \%$ for species of eucalyptus commonly used as substitutes for native species for the production of charcoal. On the other hand, Dias Júnior et al. (2019) observed levels of lignin that varied from $23.68 \%$ to $32.80 \%$ for species from the 
Caatinga, corroborating the values observed in this work. With regard to Cocos nucifera (coconut shell), our results were also elevated, superior to those observed by Cardoso and Gonçalez (2016) (19.47\%).

According to Costa et al. (2014), the higher the lignin content, the lower the holocellulose content, since the holocellulose content is obtained by difference. Lignin has higher thermal stability than carbohydrates in plant biomass. Thus, high levels of this component in biomass imply resistance to burning and combustion durability, essential to characterize biomass for energy purposes and quite relevant for use in furnaces (Cabral et al., 2017; Protásio et al., 2014; Kumar et al., 2019), not requiring frequent biomass replacement and maintaining the cooking/roasting temperature in the furnaces.

The holocellulose content corresponds to a fraction of the wood rich in carbohydrates, resulting from the sum of the cellulose and hemicellulose contents - which are the constituents that present the greatest thermal instability (Neves et al., 2013). According to Garcia-Velásquez and Cardona (2019), high levels of holocellulose suggest the use of residual raw material to produce ethanol. The results obtained for this parameter showed a statistical difference between treatments, with the highest value for Poincianella pyramidalis (69.11\%). Cocus nucifera showed the lowest content of holocellulose (42.01\%), below the value found by Cardoso and Gonçalez (2016) (46.84\%) and Cabral et al. (2017) (57.27\%). For Demirbas (2004) and Protásio et al. (2012), high levels of total extracts and low content of holocellulose may be beneficial for energy production. Yang et al. (2007) and Protásio et al. (2013a) also studied this aspect and concluded that holocellulose represents the quantity of structural polysaccharides of low thermal resistance and provides the fastest degradation during the combustion process, not being a desirable parameter for use in furnaces. Thus, according to Shen et al. (2010) and Carneiro et al. (2017), when the intention is the use as firewood or the production of charcoal, raw materials with low levels of holocellulose are desirable, as this compound contributes with little energy yield, but with high production of condensable and non-condensable gases.

\subsection{Proximate analysis}

The compositions of species samples referring to the contents of volatile materials, fixed carbon and ash, which help to identify biomasses with better properties for use in ovens, are compiled in Table 2.

Table 2. Content of volatile materials (TMV), ash (TCZ) and fixed carbon (TCF).

\begin{tabular}{cccc}
\hline Species & TMV (\%) & TCZ (\%) & TCF (\%) \\
\hline Cocos nucifera & $66.14^{(0.12)} \mathrm{c}$ & $4.22^{(0.10)} \mathrm{a}$ & $29.62^{(0.12)} \mathrm{a}$ \\
Poincianella pyramidalis & $77.05^{(0.19)} \mathrm{a}$ & $1.41^{(0.02)} \mathrm{b}$ & $21.53^{(0.18)} \mathrm{c}$ \\
& & & \\
Croton sonderianus & $77.15^{(0.47)} \mathrm{a}$ & $0.69^{(0.10)} \mathrm{d}$ & $22.16^{(0.50)} \mathrm{c}$ \\
Piptadenia stipulacea & $70.60^{(0.26)} \mathrm{b}$ & $1.18^{(0.05)} \mathrm{c}$ & $28.22^{(0.26)} \mathrm{b}$ \\
\hline
\end{tabular}

Values in parentheses refer to the standard deviation. Means followed by equal symbols in the column do not differ at $5 \%$ significance, according to the Tukey test. Source: Authors.

The presence of volatile materials in the biomass facilitates their ignition in the furnaces, providing a more efficient and homogeneous combustion (Protásio et al., 2017). Thus, among the studied species, Poincianella pyramidalis and Croton sonderianus did not show any significant difference, unlike Piptadenia stipulacea and Cocos nucifera. Among these species, the highest volatile content was exhibited by Croton sonderianus, however this value was lower than that reported by Santos et al. (2013) (87.44\%). Cocos nucifera produced the lowest value of the parameter (66.14\%), lower than that determined by Rout et al. (2016) (75.5\%). 
According to Di Blasi (1993) and Macedo et al. (2014), while lignin is more likely to form a solid by-product, holocellulose tends to decompose into volatile products (Yang et al., 2007 and Protásio et al., 2013a). Therefore, there must be a correlation between the content of holocellulose (HOL) and the content of volatile materials (TMV) (Figure 2a). Experimental data corroborate this hypothesis, as the two species that had the lowest content of holocellulose, Cocos nucifera and Piptadenia stipulacea, also had the lowest content of volatile materials.

As stated by Gioda (2018), in the biomass burning processes, incomplete combustion leads to the formation of gases such as carbon monoxide (CO), methane ( $\mathrm{CH} 4)$, nitrogen oxides (NOx) and sulfur oxides (SOx), organic compounds volatile (VOC) and particulate materials, arising from the decomposition of firewood in the ovens. For Alves et al. (2015), the total emission of pollutants in food preparation results both from combustion and from the food itself, which generates volatilized organic substances (Kabir \& Kim, 2011). In incomplete combustion, according to Li et al. (2016a) and Riva et al. (2011), when analyzing volatile coal materials for heating and cooking, concluded that pollutant gas emissions generate negative impacts on human health, such as the development of respiratory, cardiopulmonary diseases and carcinogenic effects, due to the exposure to stoves, predominantly of women, who use ovens and stoves more frequently (Wang et al., 2018).

In the production of cassava flour, roasting is the crucial step, giving characteristics such as odor, color, texture and flavor to the product (Oladejo et al., 2016), however, in the context previously discussed, the heating and roasting of the cassava bulk and emit vapors, volatile compounds and particulate matter in the indoor atmosphere of flour mill (SEBRAE, 2006), what intensifies the overall pollution of the process.

Figure 2. Correlation between the content of holocellulose (HOL), the content of volatile materials (TMV) (a) and ash content (TCZ) (b) for the species and for the residue of Cocos nucifera.

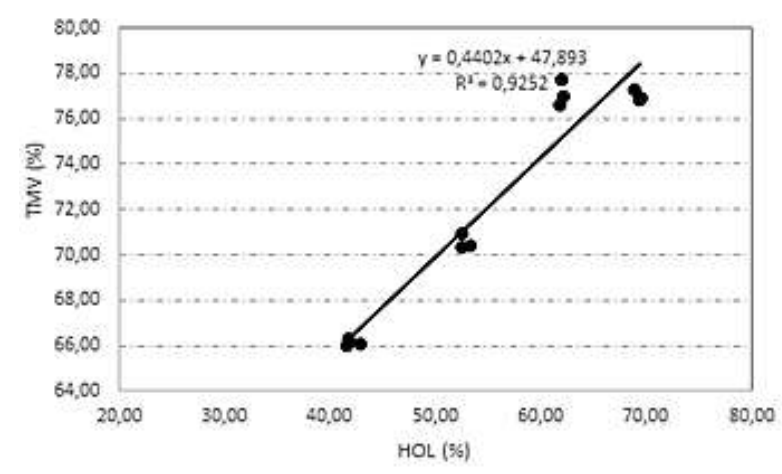

(a)

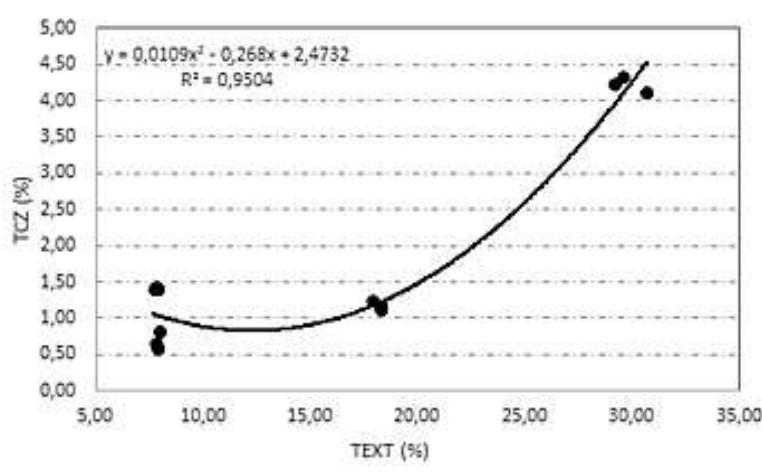

(b)

Source: Authors.

Oliveira et al. (2019) analyzed charcoal and reported that high ash contents indicate low quality of cooking coal, since the inorganic material present in the fuel reduces its calorific value. Cocos nucifera was the species that resulted in the highest ash content, close to the value found by Rout et al. (2016) (3.20\%), but below the value determined by Esteves et al. (2015) $(8.23 \%)$, who studied the fiber and shell of Cocos nucifera (green coconut) for the production of briquettes. The ashes also present the drawback of increasing the formation of deposits and corrosion inside the equipments (Fernandes et al., 2013; Jenkins et al., 1998; Pelanda et al., 2015). In the present study, the ash content showed a direct correlation with the total extractives content, due to the presence of salts and minerals in the extracts (Figure 2b).

The fixed carbon content represents the fraction of the fuel that contains carbon and oxygen (Parikh et al., 2007), related to the lignin content, whose molecule has aromatic rings, with higher binding energy than the other components (Atkins \& Jones 2006). Thus, the higher the lignin content, the higher the fixed carbon content of fuels (Protásio et al., 2014). The experimental 
results revealed the highest fixed carbon content for Cocos nucifera (29.62\%), differing statistically from the other treatments, together with Piptadenia stipulacea, which also presented a similar correlation, showing high levels of lignin and fixed carbon.

In accordance with Protásio et al. (2013a) and Protásio et al. (2014), the higher the fixed carbon content, the slower the combustion of biomass in stoves, boilers and ovens. According to Nogueira and Lora (2000), it is preferable to use fuels with higher amounts of fixed carbon as a source of bioenergy, a characteristic represented in this work by the species Cocos nucifera and Piptadenia stipulacea.

Regarding the immediate composition, among the species studied, the most recommended for use in furnaces are Piptadenia stipulacea - for having low ash content and high fixed carbon content, and Cocos nucifera - for having the highest fixed carbon content, implying a longer burning time, less volatile content, with the possibility of reducing the emission of polluting gases, when compared to other species. The higher ash content presented by Cocos nucifera, taking into account its use in the rural area, does not represent a problem, since the ash is widely used as a soil acidity corrector. Although the ash has a variable composition, they have characteristics that indicate benefits in agricultural use (Arruda et al., 2016), but this requires the attention of a specialist, to avoid undesirable effects.

\subsection{Heat of combustion}

For energy purposes, according to Carneiro et al. (2014), heating value is one of the main properties used in the selection of certain biomass as an energy source, as it is associated with the amount of energy that is released during burning. Table 3 presents the results obtained for all studied species.

Table 3. Heating values (HHV and LHV) for the investigated species.

\begin{tabular}{ccc}
\hline Species & HHV $\left(\mathbf{M J . k \mathbf { k g } ^ { - 1 } )}\right.$ & LHV $\left(\mathbf{M J . k \mathbf { k g } ^ { - 1 } )}\right.$ \\
\hline Cocos nucifera & $18.73^{(0.05)} \mathrm{c}$ & $17.46^{(0.05)} \mathrm{c}$ \\
Poincianella pyramidalis & $18.24^{(0.11)} \mathrm{d}$ & $16.97^{(0.11)} \mathrm{d}$ \\
Croton sonderianus & $19.61^{(0.09)} \mathrm{b}$ & $18.34^{(0.09)} \mathrm{b}$ \\
Piptadenia stipulacea & $20.18^{(0.17)} \mathrm{a}$ & $18.91^{(0.17)} \mathrm{a}$ \\
\hline
\end{tabular}

Values in parentheses refer to the standard deviation. Means followed by equal symbols in the column do not differ at $5 \%$ significance, according to the Tukey distribution. Source: Authors.

The average values for the PCS reported in this work, which are indispensable for comparing the energetic power of biomasses (Protásio et al., 2013b), showed significant differences of up to 5\%, but in agreement with the values reported by

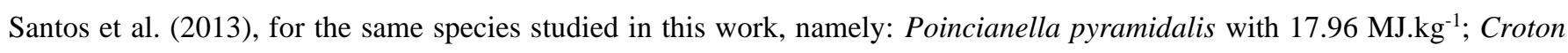

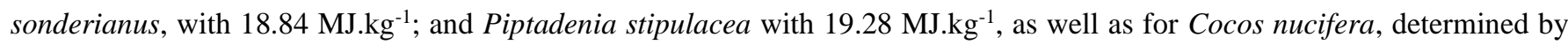

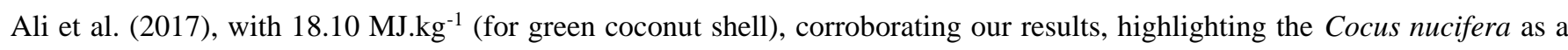
potential substitute for firewood commonly used in the studied region. A similar fact occurred for the LHV parameter, which also showed significant differences (up to about 5\%), but in agreement with the results of Lima Júnior et al. (2015), when analyzing the economic viability of the energetic use of caatinga firewood under sustainable management for forest species such as Mimosa tenuiflora (18.12 MJ.kg-1). Protásio et al. (2014), studying the energetic potential of babassu coconut for the production of charcoal, found an LHV of 17.16 MJ.kg-1, compatible with the result reported here.

The calorific value is a parameter linked to the chemical properties of a biomass (Araújo et al., 2018). According to Bufalino et al. (2012), Sharma et al. (2004) and Demirbas (2001), the higher are the lignin and the fixed carbon contents, the 
greater is the calorific value of the fuels, which can be attributed to the carbon-carbon bonds between the monomeric units of phenyl-propane present in the lignin, which hinder its decomposition. Therefore, there is a relationship between HHV and lignin content (TLIG) (Figure 3A), and between PCS and fixed carbon content (TCF) (Figure 3B). It is evident that the LHV is directly influenced by these two parameters, since the higher TLIG implies in HHV also high, nevertheless, the species that present lower values for the TCF presented high values for the content of volatile materials (TMV), a parameter that exhibits an opposite behavior to the fixed carbon content in charcoal (Santos et al., 2016).

Figure 3. Correlation between higher heating value (HHV), lignin content (TLIG) (a) and fixed carbon content TCF (b), for the analyzed species.

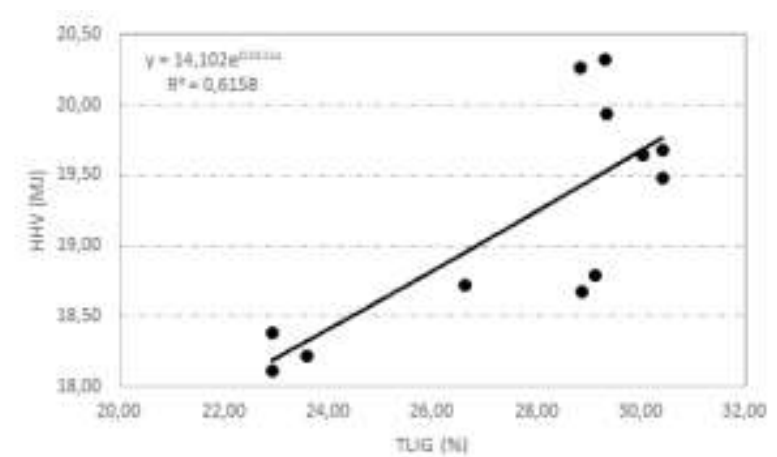

(a)

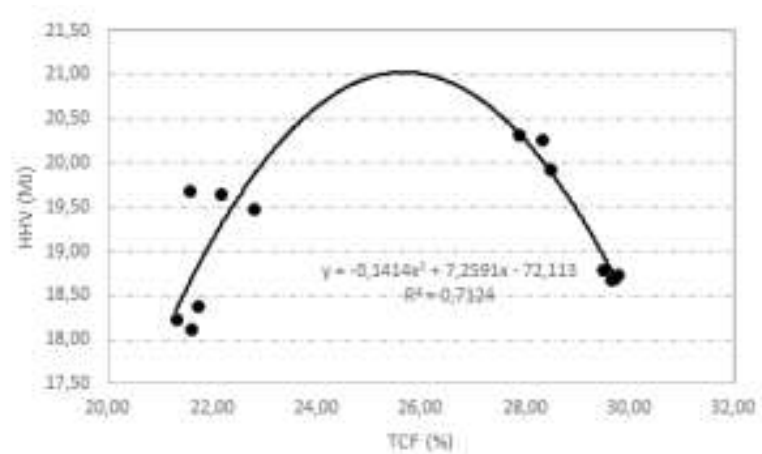

(b)

Souce: Authors.

In addition to lignin, the content of total extracts is also related to the calorific value, influencing the burning process, cooking food, constituting itself an advantageous feature for energy production, due to the high calorific value of the components of the extracts (Telmo \& Lousada, 2011; Guo et al., 2010), which promote an increase in the calorific value of biomass (Telmo \& Lousada, 2011). Another property related to the calorific value, relevant to the analysis of biomass in the burning process, is the ash content, which reduces its calorific value (Paula et al., 2011; Protásio et al., 2011).

\subsection{Thermogravimetric Analysis}

The thermal behavior revealed by the thermograms (Figure 4) is directly related and influenced by the composition of the biomass. 
Figure 4. Thermogravimetric (TG) and derived (DTG) curves for: (a) Poincianella pyramidalis; (b) Croton sonderianus; (c) Piptadenia stipulacea and (d) Cocos nucifera.

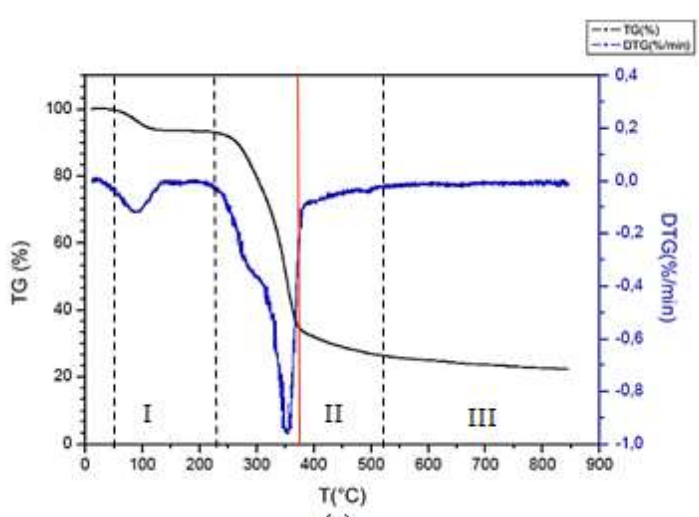

(a)

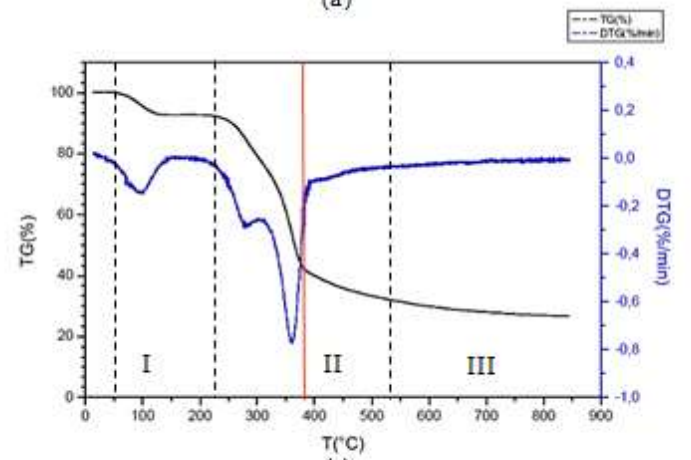

(c)

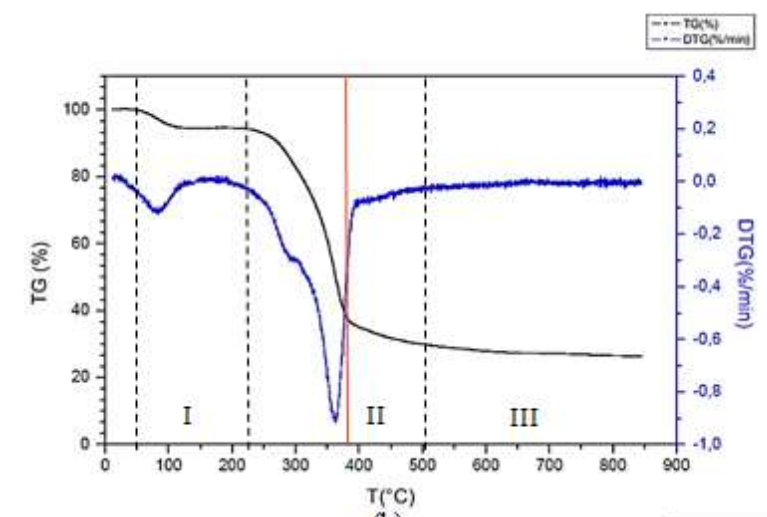

(b)

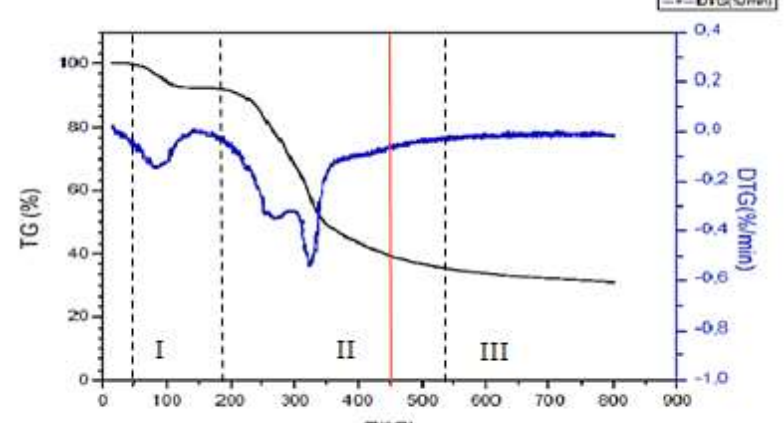

(d)

Fonte: Authors.

On the word of Padilla et al. (2018), who studied the pyrolysis of agricultural residual biomass using thermogravimetric analysis, the thermal degradation of the constituents changes significantly with the chemical and immediate composition, in a way that each biomass has different thermal profiles depending on its structural compositions. Thus, it is noticed the loss of mass with the increase in temperature and its first derivative for the studied species, which presented similar behaviors, with similar mass loss profiles, but with some particular characteristics of each studied biomass (Figure 4). Two main thermal events are observed (I and II), in which (I) corresponds to the drying step, with evaporation of the water present in the biomass between $50^{\circ} \mathrm{C}$ and $200^{\circ} \mathrm{C}$ - for Cocos nucifera, remaining constant until $200^{\circ} \mathrm{C}$, and between $50^{\circ} \mathrm{C}$ and $250^{\circ} \mathrm{C}$ - for Piptadenia stipulacea, Poincianella pyramidalis and Croton sonderianus, remaining constant up to $250^{\circ} \mathrm{C}$. It is a stage with a slight loss of mass (less than 10\%) for all analyzed species and the beginning of the release of volatile materials (Marcelino et al., 2017). It is also possible to note the loss of mass of each species at this stage, with the species Piptadenia stipulacea and Cocos nucifera showing the highest losses of mass (8\%) in this first stage of degradation (Table 4). Event (II) occurred between $200^{\circ} \mathrm{C}$ and $530^{\circ} \mathrm{C}$ for $\mathrm{Cocos}$ nucifera, and between $250^{\circ} \mathrm{C}$ and $530^{\circ} \mathrm{C}$ for the species Piptadenia stipulacea, Poincianella pyramidalis and Croton sonderianus, characterized as a primary combustion - oxidative degradation (Galina et al., 2018), in which the greatest loss of mass occurs rapidly, due to the thermal decomposition of carbohydrates, which can be attributed to the volatization and breakdown of hemicellulose and cellulose (holocellulose) molecules (Dias Júnior et al., 2019). However, in these temperature ranges, each species showed a different percentage of mass loss, with Poincianella pyramidalis being the one with the greatest loss of mass (approximately 73\%) and Cocos nucifera that one with the least loss of mass (approximately 64\%) (Table 4). After $530^{\circ} \mathrm{C}$, there is less significant loss of mass, with less intensity, due to the decomposition of the lignin macromolecule (Protásio et al., 2014). As the decomposition of the chemical constituents of biomass does not occur separately, there is an overlap of the 
decomposition of hemicellulose and cellulose (Galina et al., 2018), generating the carbonization products throughout the process, which continued to decompose from $530^{\circ} \mathrm{C}$.

According to Skreiberg et al. (2011), the complex structure of lignin gives it thermal stability, makes it the most difficult component to degrade, slowly decomposing over a wide temperature range, up to $900^{\circ} \mathrm{C}$ (Yang et al., 2007). This configures the third thermal event (III), which occurs from $530^{\circ} \mathrm{C}$ to approximately $850^{\circ} \mathrm{C}$, with a predominance of lignin breakage, which occurs with a much lower mass loss rate among the species studied (Burhenne et al., 2013), with no specific degradation range or peak temperature corresponding to lignin being detected (Sobek \& Werle, 2020).

Table 4. Loss of mass and characteristic temperatures.

\begin{tabular}{cccc|c|c}
\hline Species & Tig & Tp & \multicolumn{3}{c}{ Loss of mass (\%) } \\
\cline { 5 - 7 } & $\left({ }^{\circ} \mathbf{C}\right)$ & $\left({ }^{\circ} \mathbf{C}\right)$ & $(\mathbf{5 0 - 2 0 0})^{\circ} \mathbf{C}$ & $(\mathbf{2 5 0}-\mathbf{5 3 0})^{\circ} \mathbf{C}$ & $(\mathbf{5 3 0}-\mathbf{8 5 0})^{\circ} \mathbf{C}$ \\
\hline Cocos nucifera & 180 & 450 & 8 & 64 & 8 \\
Poincianella pyramidalis & 230 & 380 & 7 & 73 & 5 \\
Croton sonderianus & 230 & 390 & 6 & 70 & 6 \\
Piptadenia stipulacea & 230 & 390 & 8 & 67 & 7 \\
\hline
\end{tabular}

Where: Tig - ignition temperature; Tp - peak temperature. Source: Authors.

The ignition temperature (Table 4) is reached when volatile materials start to detach, corresponding to the point where there is a sudden increase in thermal degradation (Cao et al., 2017). For woody biomass, the ignition temperature was approximately $230^{\circ} \mathrm{C}$, however, for Cocos nucifera, this temperature was $180^{\circ} \mathrm{C}$, consistent with the results obtained by Chansa et al. (2020), who found an ignition temperature range of $225-250^{\circ} \mathrm{C}$, when studying corn and coal residues.

According to Guo et al. (2020b), biomass has higher levels of volatile materials when compared to coal, thus presenting lower ignition temperatures. The reduction in the ignition temperature is associated with an increase in the reactivity of the material, ease of burning and an improvement in the combustion performance (Galina et al., 2018). Among the species analyzed, the woody ones had higher ignition temperatures than Cocos nucifera, as observed by Li et al. (2016b) when studying strawtype biomass that starts its decomposition at low temperatures, with the first peak of the curve at $313{ }^{\circ} \mathrm{C}$, while wood requires higher temperatures to start thermal conversion, around $352^{\circ} \mathrm{C}$.

The peak temperature (represented by the thick red line in the graph), which corresponds to the point at which the maximum loss of mass occurs, due to the combustion of the biomass, which reached approximately $450^{\circ} \mathrm{C}$ for $\operatorname{Cocos}$ nucifera, whereas for the other species studied, the peak was between $380^{\circ} \mathrm{C}$ and $400^{\circ} \mathrm{C}$ (Table 4), which means more intense decomposition at higher temperatures. Such results were superior to those reported by Protásio et al. (2014), who registered a peak temperature of $303^{\circ} \mathrm{C}$ for babassu coconut. Therefore, the results of this study demonstrate the suitability of coconut shells as a fuel for the generation of heat in combustors.

\section{Conclusion}

The residual biomass of Cocos nucifera (coconut shell) has significant energy potential compared to the other studied biomasses, commonly used as a source of thermal energy through direct burning. The results of the present study exhibited high levels of total lignin, fixed carbon, HHV and LHV, which are important characteristics for the sustainable production of energy, ensuring that Cocos nucifera can be a viable substitute for use in combustors of biomass in a general way, especially in furnaces 
for the production of cassava flour, reducing the need for extraction of firewood from the Caatinga biome, contributing to its conservation and preservation.

The preliminary results presented in this work were very motivating, which encourages us to carry out more advanced research on the subject, highlighting: use of coconut shell as fuel in full-scale flour house ovens; to carry out economic feasibility and sustainable management studies, in partnership with researchers in the field of forest sciences, for the supply of biomass under study to meet the specific energy demand of the cassava flour production activity in the municipality that supported the present study.

\section{Acknowledgments}

Carolina Oliveira Souza thanks the Department of Forestry and Wood Sciences, Campus Nedetc, Federal University of Espírito Santos, for the partnership in carrying out laboratory analyses, the Coordination for the Improvement of Higher Education Personnel (Capes) and the Foundation for Research and Support Technological Innovation of the State of Sergipe (Fapitec), for the master's scholarship (Edict Fapitec/Capes 07/2018) and for the cost of the expedition to Espírito Santo, with resources from Project no: 88881.157938/2017-01.

\section{References}

Ahrends, A., Burgess, N. D., Milledge, S. A. H., Bulling, M. T., Fisher, B., Smart, J. C. R., Clarke, G. P., Mhoro, B. E., \& Lewis, S. L. (2010). Predictable waves of sequential forest degradation and biodiversity loss spreading from an African city. PNAS, 107 (33), $14556-61$.

Almeida, A. M. C., Oliveira, E., Calegari, L., Neto, P. N. M., \& Pimenta, A. S. (2015). Avaliação físico-química e energética da madeira das espécies Piptadenia stipulacea (Benth,) Duckeand Amburana cearenses (Allemao) A. C. Smith de ocorrência no semiárido nordestino brasileiro. Ciência Florestal, 25 (1), 165-173. https://doi.org/10.1590/1980-509820152505165

Alves, C. A., Evtyugina, M., Cerqueira, M., Nunes, T., Duarte, M., \& Vicente, E. (2015). Volatile organic compounds emitted by the stacks of restaurants. Air Qual Atmos Health, 8, 401-412. https://doi.org/10.1007/s11869-014-0310-7

APL-SE. 2011. Plano de desenvolvimento preliminar do arranjo produtivo local da mandioca no agreste e centro-sul sergipano. Núcleo Estadual de Arranjos Produtivos Locais, Secretaria de Estado do Desenvolvimento Econômico e da Ciência e Tecnologia.

Araújo, A. C. C., Costa, L. J., Braga, P. P. C., Neto, R. M. G., Rocha, M. F. V., \& Trugilho, P. F. (2018). Propriedades energéticas da madeira e do carvão vegetal de Cenostigma macrophyllum: subsídios ao uso sustentável. Pesquisa Florestal Brasilera, 38, 1-9. 10.4336/2018.pfb.38e201701546

Arruda, J. A., Azevedo, T. A. O., Freire, J. L. O., Bandeira, L. B., Estrela, J. W. M., \& Santos, S. J. A. (2016). Uso da cinza de biomassa na agricultura: efeitos sobre atributos do solo e resposta das culturas. Revista Principia, 30. 10.18265/1517-03062015v1n30p18-30

Atkins, P., \& Jones, L. (2006). Princípios De Química: Questionado a Vida Moderna e o Meio Ambiente.

Brady, M. P., Banta, K., Mizia, J., Lorenz, N., Leonard, D. N., Yamamoto, Y., Defoort, M., \& Keiser, J. R. (2017). Alloy Corrosion Considerations in LowCost, Clean Biomass Cookstoves for the DevelopingWorld. Energy for Sustainable Development, 37, 20-32.

Bufalino, L., Protásio, T. P., Couto, A. M., Nassur, O. A. C., De Sá, V. A., Trugilho, P. F., \& Mendes, L. M. (2012). Caracterização química e energética para aproveitamento da madeira de costaneira e desbaste de cedro australiano. Pesquisa Florestal Brasileira, 32 (70), $129-137$.

Burhenne, L., Messmer, J., Aicher, T., \& Laborie, M-P. (2013). The effect of the biomass components lignin, cellulose and hemicellulose on TGA and fixed bed pyrolysis. Journal of Analytical and Applied Pyrolysis, 101, 177-184. https://doi.org/10.1016/j.jaap.2013.01.012

Cabral, M. M. S., Abud, A. K. S., Rocha, M. S. R. S., Almeida, R. M. R. G., \& Gomes, M. A. (2017). Composição da fibra do coco verde in natura e após prétratamentos químicos. ENGEVISTA, 19 (1), 99-108. https://doi.org/10.22409/engevista.v19i1.802

Campbell, J. E., Lobell, D. B., Genova, R. C., \& Field, C. B. (2008). The Global Potential of Bioenergy on Abandoned Agriculture Lands. Environ. Sci. Technol, 42, 5791-94.

Cao, W., Li, J., \& Lue, L. (2017). Study on the ignition behavior and kinetics of combustion of biomass. Energy Procedia, 142, 136-141. https://doi.org/10.1016/j.egypro.2017.12.022

Cardoso, M. S., \& Gonçalez, J. C. (2016). Aproveitamento da casca do coco verde (Cocos nucifera L.) para produção de polpa celulósica. Ciência Florestal, 26 (1), 321-330. http://dx.doi.org/10.5902/1980509821126

Carneiro, A. C. O., Castro, A. F. N. M., Castro, R. V. O., Santos, R. C., Ferreira, L. P., Damásio, R. A. P., \& Vital, B. R. (2014). Potencial energético da madeira de eucalyptus sp. em função da idade e de diferentes materiais genéticos. Revista Árvore, 38 (2), 375-381. 
Carneiro, A. C. O., Vital, B. R., Frederico, P. G. U., Figueiró, C. G., Fialho, L. De F., \& Silva, C. M. S. Da. (2017). Caracterização energética das madeiras de clones de Eucalyptus cultivados em diferentes localidades. Revista Ciência da Madeira, 8 (3), 127-135.

Cereda, M. P., \& Vilpoux, O. (2003). Tecnologia, usos e potencialidades de tuberosas amiláceas latino americanas. Fundação Cargill.

Cereda, M. P., \& Vilpoux, O. (2010). Metodologia para divulgação de tecnologia para agroindústrias rurais: exemplo do processamento de farinha de mandioca no Maranhão. Revista Brasileira de Gestão e Desenvolvimento Regional, 6 (2), 219-250.

Chansa, O., Z, Luo., \& C, Yu. (2020). Study of the kinetic behaviour of biomass and coal during oxyfuel co-combustion. Chinese Journal of Chemical Engineering, 28 (7), 1796-1804. https://doi.org/10.1016/j.cjche.2020.02.023

Costa, T. G., Bianchi, M. L., Protásio, T. P., Trugilho, P. F., \& Pereira, A. J. (2014). Qualidade da madeira de cinco espécies de ocorrência no cerrado para produção de carvão vegetal. Cerne, 20 (1), 37-46. https://doi.org/10.1590/S0104-77602014000100005

CPRM. (2002). Serviço Goelógico do Brasil - Projeto Cadastro da Infra-Estrutura Hídrica do Nordeste/Estado de Sergipe - Diagnóstico do Município de São Domingos.

Demirbas, A. (2002). Relationships between lignin contents and heating values of biomass. Energy Conversion and Management, 42 (2). https://doi.org/10.1016/S0196-8904(00)00050-9

Demirbas, A. (2002). Relationships between heating value and lignin, moisture, ash and extractive contents of biomass fuels. Journal Energy, Exploration \& Exploitation, 20 (1), 135-143. https://doi.org/10.1260/014459802760170420

Di Blasi, C. (1993). Modeling and simulation of combustion processes of charring and non-charring solid fuels. Progress in Energy and Combustion Science, 19. https://doi.org/10.1016/0360-1285(93)90022-7

Dias Júnior, A. F., Andrade, C. R., Protásio, T. P., Brito, J. O., Trugilho, P. F., Oliveira, M. P., \& Dambroz, G. B. V. (2019). Thermal profile of wood species from brazilian semi-arid region submitted to pyrolysis. Cerne, 25 (1), 44-53.

Esteves, M. R. L., Abud, A. K. S., \& Barcellos, K. M. (2015). Avaliação do potencial energético das cascas de coco verde para aproveitamento na produção de briquetes. Revista Scientia Plena, 11 (3).

Fernandes, E. R. K., Marangoni, C., Souza, O., \& Sellin, N. (2013). Thermochemical characterization of banana leaves as a potencial energy source. Energy Conversion and Management, 75, 603-608. https://doi.org/10.1016/j.enconman.2013.08.008

Foel, W., Pachauri, S., Spreng, D., \& Zerriffi, H. (2011). Household cooking fuels and technologies in developing economies. Energy Policy, 39 , 7487-96.

Galina, N. R., Luna, C. M. R., Arce, G. L. A. F., \& Ávila, I. (2018). Comparative study on combustion and oxy-fuel combustion environments using mixtures of coal with sugarcane bagasse and biomass sorghum bagasse by the thermogravimetric analysis. Journal of the Energy Institute, 92 (3), 741-754. https://doi.org/10.1016/j.joei.2018.02.008

Garcia-Velásquez, C. A., \& Cardona, C. A. (2019). Comparison of the biochemical and thermochemical routes for bioenergy production: A techno-economic (TEA), energetic and environmental assessment. Fuel, 172, 232-242. https://doi.org/10.1016/j.energy.2019.01.073

Gil, A. C.(2010). Como elaborar projetos de pesquisa. 5. ed. São Paulo: Atlas.

Gioda, A. (2018). Comparação dos níveis de poluentes emitidos pelos diferentes combustíveis utilizados para cocção e sua influência no aquecimento global. Química Nova, 41 (8), 839-848. http://dx.doi.org/10.21577/0100-4042.20170260

Gioda, A. (2019). Residential fuelwood consumption in Brazil: environmental and social implications. Biomass and Bioenergy, 120, 367-375. https://doi.org/10.1016/j.biombioe.2018.11.014

Gnansounou, E., Pachón, E. R., Sinsin, B., Teka, O., Togbé, E., \& Mahamane, A. (2020). Using agricultural residues for sustainable transportation biofuels in 2050: Case of West Africa. Bioresource Technology. https://doi.org/10.1016/j.biortech.2020.123080

Guo, X., Wang, S., Wang, K., liu, Q., \& Luo, Z. (2010). Influence of extractives on mechanism of biomass pyrolysis. Journal of Fuel Chemistry and Technology, 38 (1), 42-46. https://doi.org/10.1016/S1872-5813(10)60019-9

Guo, M., H Van dam, K., Touhami, N. O., Nguyen, R., Delval, F., Jamieson, C., \& Shah, N. (2020a). Multi-level system modelling of the resource-foodbioenergy nexus in the global South. Energy, 197, 1-12.

Guo, F., He, Y., Hassanpour, A., Gardy, J., \& Zhong, Z. (2020b). Thermogravimetric analysis on the combustion of biomass pellets, coal and their blends. Energy, 197. https://doi.org/10.1016/j.energy.2020.117147

Hosonuma, N., Herold, M., De Sy, V., De Fries, R. S., Brockhaus, M., Vercht, L., Angelsen, A., \& Romijn, E. (2012). An assessment of deforestation and forest degradation drivers in developing countries. Environmental Research Letter, 7 (4), 1-12. 10.1088/1748-9326/7/4/044009

Inventário Florestal Nacional (IFN). IFN - SE. (2018). Serviço Florestal Brasileiro - Inventário Florestal Nacional Sergipe. Ministério do Meio Ambiente. Série Relatórios Técnicos - IFN. Brasília - DF.

Jan, I. (2012). What makes people adopt improved cookstoves? Empirical evidence from rural northwest Pakistan. Renewable and Sustainable Energy Reviews, $16,3200-05$.

Jenkins, B. M., Baxter, L. L., Miles Jr, T. R., \& Miles, T. R. (1998). Combustion properties of biomass. Fuel Processing Technology, 54 (1), 17-46. https://doi.org/10.1016/S0378-3820(97)00059-3 
Kabir, E., \& Kim, K. H. (2011). An investigation on hazardous and odorous pollutant emission during cooking activities. Journal of Hazardous Materials, 188, 443-454. https://doi.org/10.1016/j.jhazmat.2011.01.113

Klock, U., Andrade, A. S., Silva, E. L., Moura, G. B., Potulski, D., Barbosa, T. F., \& Silva, D. H. R. (2012). Manual e fichas para prática de análises químicas quantitativas da madeira. Laboratório de Química da Madeira. Universidade Federal do Paraná. Curitiba - PR.

Kumar, M., Upadhyay, S. N., \& Mishra, P. K. (2019). A comparative study of thermochemical characteristics of lignocellulosic biomasses. Bioresource Technology Reports, 8, 1-8. https://doi.org/10.1016/j.biteb.2019.100186

Lewis, J. J., \& Pattanayak, S. K. (2012). Who Adopts Improved Fuels and Cookstoves? A Systematic Review. Environmental Health Perspectives, 120 (5), $637-$ 645. 10.1289/ehp.1104194

Li, Q., Jiang, J., Zhang, Q., Zhou, W., Cai, S., Duan, L., Ge, S., \& Hao, J. (2016a). Influences of coal size, volatile matter content, and additive on primary particulate matter emissions from household stove combustion. Fuel, 182, 780-787. https://doi.org/10.1016/j.fuel.2016.06.059

Li, J., Paul, M. C., \& Czajka, K. M. (2016b). Studies of Ignition Behavior of Biomass Particles in a Down-Fire Reactor for Improving Co-firing Performance. Energy Fuels, 30 (7), 5870-77. https://doi.org/10.1021/acs.energyfuels.6b01065

Lima Júnior, C., Lima, R. L. F., Liberal, B. G., Guerrero, J. R. H., Sampaio, E. V. S. B., \& Menezes, R. S. C. (2015). Viabilidade Econômica do Uso Energético de Lenha da Caatinga sob Manejo Sustentável. Revista Brasileira de Geografia Física, 8 (1), 156-166. https://doi.org/10.26848/rbgf.v8.1.p156-166

Macedo, L. A., Rousset, P. L. A., \& Vale, A. T. (2014). Effect of biomass composition on the condensable gas yield from torrefaction of plants residues. Revista Florestal Brasileira - PFB, 34 (80), 417-424. https://doi.org/10.4336/2014.pfb.34.80.747

Machado, M. F., Gomes, L. J., \& Mello, A. A. (2010). Caracterização do consumo de lenha pela atividade cerâmica no estado de Sergipe. Revista Floresta, 40 (3), 507-514. http://dx.doi.org/10.5380/rf.v40i3.18912

Marcelino, M. M., Melo, S. A. B. V., \& Torres, E. A. (2017). Caracterização da biomassa da casca do coco para obtenção de energia. BAHIA ANÁLISE \& DADOS $-B A \& D, 27(1), 336-355$.

Marconi, M. A., \& Lakatos, E. M. (2010). Fundamentos de metodologia científica. 7 ed. São Paulo: Atlas.

Mehmood, M. A., Ahmad, M. S., Liu, Q., Liu, C. G., Tahir, M. H., Aloqbi, A. A., Tarbiah, N. I., Alsufiani, H. M., \& Gull, M. (2019). Helianthus tuberosus as a promising feedstock for bioenergy and chemicals appraised through pyrolysis, kinetics, and TG-FTIR-MS based study. Energy Conversion and Management, 194, 37-45. https://doi.org/10.1016/j.enconman.2019.04.076

Morais, J. P. S., Rosa, M. F., \& Marconcini, J. M. (2010). Procedimento para análise lignocelulósica. EMBRAPA - Documentos 236. Campina Grande - PB.

Moro, M. F., Lughadha, E. N., Araújo, F. S., \& Martins, F. R. (2016). A phyto geographical meta analysis of the semiarid caatinga domain in Brazil. The Botanical Review. 10.1007/s12229-016-9164-z

Muscat, A., De Olde, E. M., De Boer, I. J. M., \& Ripoll-Bosch, R. (2020). The battle for biomass: A systematic review of food-feed-fuel competition. Global Food Security, 25. https://doi.org/10.1016/j.gfs.2019.100330

Neves, T. A., Protásio, T. P., Trugilho, P, F., Valle, M. L. A., Sousa, L. C., \& Vieira, C. M. M. (2013). Qualidade da madeira de clones de Eucalyptus em diferentes idades para a produção de bioenergia. Revista de Ciências Agrárias, 56 (2), 139-148. http://dx.doi.org/10.4322/rca.2013.022

Neves, E. C. A., Neves, D. A., Lobato, K. B. S., Nascimento, G. C., \& Clerici, M. T. P. S. (2017). Technological aspects of processing of cassava derivatives. In: Clarissa Klein. Handbook on Cassava - Production, Potencial uses and recent advences. Nova Science Publishers.

Nogueira, H. L. A., \& Lora, E. E. S. (2000). Dendroenergia: Fundamentos e Aplicações. Editora Interciência. (2a ed.).

Oladejo, D., Mark, O., AdedejI, K. A., \& Oluoti, K. O. (2016). Determination of Energy Profile in Processing Cassava (Manihot species) into 'Gari' in a Local Oven. Journal of Scientific Research \& Reports, 11 (2), 1-8. 10.9734/JSRR/2016/25522

Oliveira, R. S., Silva, L. F. F., Andrade, F. W. C., Trugilho, P. F., Protásio, T. P., \& Goulart, S. L. (2019). Quality of charcoal marketed in southeast Pará for cooking foods. Revista de Ciências Agrárias, 62, 1-9. http://dx.doi.org/10.22491/rca.2019.3017

Padilla, E. R. D., Belini, G. B., Nakashima, G. T., Waldaman, W. R., \& Yamaji, F. M. (2018). Potencial Energético da Casca de Coco (Cocos nuciferaL.) para uso na produção de carvão vegetal por pirólise. Revista Virtual de Quimica, 10 (2).

Parikh, J., Channiwala, S. A., \& Ghosal, G. K. A. (2007). A correlation for calculating elemental composition from proximate analysis of biomass materials. Fuel, 86 (12), 1710-19. https://doi.org/10.1016/j.fuel.2006.12.029

Paula, L. E. R., Trugilho, P. F., Napoli, A., \& Bianchi, M. L. (2011). Characterization of residues from plant biomass for use in energy generation. Cerne, 17 (2), 237-246. https://doi.org/10.1590/S0104-77602011000200012

Pereira, A. S., Shitsuka, D. M., Moreira, D., Parreira, F. J. \& Shitsuka, R. (2018). Metodologia da pesquisa científica. UFSM.

Pelanda, K. A., Potulski, D. C., Silva, D. A., \& Ferraz, F. A. (2015). Avaliação das possíveis implicações do uso de diferentes biomassas florestais como biocombustível em geradores de vapor. Ciência da Madeira, 6 (2), 112-121.

Poletto, M., Zattera, A. J., Forte, M. M. C., \& Santana, R. M. C. (2012). Thermal decomposition of wood: Influence of wood components and celulose crystallite size. Bioresource Technology, 109, 148-153. 
Protásio, T. P., Bufalino, L., Tonoli, G. H. D., Couto, A. M., Trugilho, P. F., \& Guimarães Júnior, M. (2011). Relação entre o poder calorífico superior e os componentes elementares e minerais da biomassa vegetal. Pesquisa Florestal Brasileira, 31 (66), 122 -133.

Protásio, T. P., Tonoli, G. H. D., Guimarães Júnior, M., Bufalino, L., Couto, A. M., \& Trugilho, P. F. (2012). Correlações canônicas entre as características químicas e energéticas de resíduos lignocelulósicos. Cerne, 18 (3), 433-439.

Protásio, T. P., Melo, I. C. N. A., Guimarães Júnior, M., Mendes, R. F., \& Truguilho, P. F. (2013a). Thermal decomposition of torrefied and carbonized briquettes of residues from coffee grain processing. Ciência e Agrotecnologia, 37 (3), 221-228. https://doi.org/10.1590/S1413-70542013000300004

Protásio, T. P., Bufalino, L., Tonoli, G. H. D., GuimarãeS Júnior, M., Trugilho, P. F., \& Mendes, L. M. (2013b). Brazilian Lignocellulosic Wastes for Bioenergy Production: Characterization and Comparison with Fossil Fuels. Bioenergy vs. fossil energy, BioReosources, 8 (1), $1166-85$.

Protásio, T. P., Couto, A. M., Reis, A. P., Trugilho, P. F., \& Godinho, T. P. (2013c). Potencial siderúrgico e energético do carvão vegetal de clones de Eucalyptus spp. aos 42 meses de idade. Pesquisa Florestal Brasileira, 33 (74), 137-149. https://doi.org/10.4336/2013.pfb.33.74.448

Protásio, T. P., Truguilho, P. F., César, A. A. S., Napoli, A., Melo, I. C. N. A., \& Silva, M. G. (2014). Babassu nut residues: potential for bioenergy use in the North and Northeast of Brazil, SpringerPlus, 3 (1), 1-14. https://doi.org/10.1186/2193-1801-3-124

Protásio, T. P., Guimarães Júnior, M., Mirmehdi, S., Trugilho, P. F., Napoli, A., \& Knovack, K. M. (2017). Combustion of biomass and charcoal made from babassu nutshell. Cerne, 23 (1), 1-10. http://dx.doi.org/10.1590/01047760201723012202

Protásio, T. P., Scatolino, M. V., Araújo, A. C. C., Oliveira, A. F. C. F., Figueiredo, I. C. R., Assis, M. R., \& Trugilho, P. F. (2019). Assessing Proximate Composition, Extractive Concentration, and Lignin Quality to Determine Appropriate Parameters for Selection of Superior Eucalyptus Firewood. BioEnergy Research, 12, 626-641.

Quinn, A. K., Bruce, N., Puzzolo, E., Dickinson, K., Sturke, R., Jack, D. W., Mehta, S., Shankar, A., Sherr, K., \& Rosenthal, J. P. (2018). An analysis of efforts to scale up clean household energy for cooking around the world. Energy for Sustainable Development, 46, 1-10.

Rípoli, T. C. C., Jr, W. F. M., \& Rípoli, M. L. C. (2000). Energy potencial of sugar cane biomass in Brazil. Scientia Agricola, 57 (4), 677-681. https://doi.org/10.1590/S0103-90162000000400013

Riva, G., Pedretti, E. F., Toscano, G., Duca, D., \& Pizzi, A. (2011). Determination of polycyclic aromatic hydrocarbons in domestic pellet stove emissions. Biomass and Bioenergy, 35, 4261-67. https://doi.org/10.1016/j.biombioe.2011.07.014

Rout, T., Pradham, D., Singh, R. K., \& Kumari, N. (2016). Exhaustive study of products obtained from coconut shell pyrolysis. Journal of Environmental Chemical Engineering, 4 (3), 3696-3705. https://doi.org/10.1016/j.jece.2016.02.024

Ruiz-Mercado, I., Masera, O., Zamora, H., \& Smith, K. R. (2011). Adoption and sustained use of improved cookstoves. Energy Policy, 39, 7557-66. https://doi.org/10.1016/j.enpol.2011.03.028

Santos, R. C. S., Carneira, A. C. O., Pimenta, A. S., Castro, R. V. O., Marinho, I. V., Trugilho, P. F., Alves, I. C. N., \& Castro, A. F. N. M. (2013). Potencial energético da madeira de espécies oriundas de plano de manejo florestal no estado do Rio Grande do Norte. Ciência Florestal, 23 (2), 491-502. http://dx.doi.org/10.5902/198050989293

Santos, R. C., Carneiro, A. C. O., Vital, B. R., Castro, R. V. O., Vidaurre, G. B., Trugilho, P. F., \& Castro, A. F. N. M. (2016). Influência das propriedades químicas e da relação siringil/guaiacil da madeira de eucalipto na produção de carvão vegetal. Ciência Florestal, 26 (2), $657-669$.

SEBRAE. (2006). Serviço de Apoio às Micro e Pequenas Empresas/SEBRAE. Manual de Referência para casas de farinha. SEBRAE - AL.

Shen, J., Zhu, S., Liu, X., Zhang, H., \& Tan, J. (2010). The prediction of elemental composition of biomass based on proximate analysis. Energy Conversion and Management, 51 (5), 983-987. https://doi.org/10.1016/j.enconman.2009.11.039

Sharma, R. K., Wooten, J. B., Baliga, V. L., Lin, X., Chan, W. G., \& Hajaligol, M. R. (2004). Characterization of chars from pyrolysis of lignin. Fuel, 83 (11), 1469-82. 10.1016/j.fuel.2003.11.015

Skreiberg, Ø. A., Sandquist, J., \& Sørum, L. (2011). TGA and macro-TGA characterisation of biomass fuels and fuel mixtures. Fuel, 90, $2182-97$. https://doi.org/10.1016/j.fuel.2011.02.012

Sobek, S., \& Werle, S. (2020). Kinetic modelling of waste wood devolatilization during pyrolysis based on thermogravimetric data and solar pyrolysis reactor performance. Fuel, 261. https://doi.org/10.1016/j.fuel.2019.116459

Telmo, C., \& Lousada, J. (2011). The explained variation by lignin and extractive contentes on higher heating value of wood. Biomass and Bioenergy, 35, 166367. 10.1016/j.biombioe. 2010.12 .038

Vassilev, S. V., Baxter, D., \& Vassileva, C. G. (2013). An overview of the behaviour of biomass during combustion: Part I. Phase-mineral transformations of organic and inorganic matter. Fuel, 112, 391-449.

Wang, H., Xiang, Z., Wang, L., Jing, S., Lou, S., Tao, S., Liu, J., Yu, M., Li, L., Lin, L., Chen, Y., Wiedensohler, A., \& Chen, C. (2018). Emissions of volatile organic compounds (VOCs) from cooking and their speciation: A case study for Shanghai with implications for China. Science of the Total Environment, 621, 1300-09. 10.1016/j.scitotenv.2017.10.098

Wicke, B., Smeets, E., Watson, H., \& Faaij, A. (2011). The current bioenergy production potential of semi-arid and arid regions in sub-Saharan Africa. Biomass and Bioenergy, 35, 2773-86.

Yang, H., Yang, R., Chen, H., Lee, D. H., \& Zheng, C. (2007). Characteristics of hemicellulose, cellulose and lignin pyrolysis. Fuel, 86 (12), $1781-88$.

Yerima, I., \& Grema, M. Z. (2018). The potencial of coconut shell as biofuel. The Journal of Middle East and North Africa Sciences, 4 (8). 